\title{
Thermosulfidibacter takaii gen. nov., sp. nov., a thermophilic, hydrogen-oxidizing, sulfur-reducing chemolithoautotroph isolated from a deep-sea hydrothermal field in the Southern Okinawa Trough
}

Correspondence

Takuro Nunoura takuron@jamstec.go.jp

\author{
Takuro Nunoura, Hanako Oida, Masayuki Miyazaki and Yohey Suzuki
}

\author{
Subground Animalcule Retrieval (SUGAR) Program, Extremobiosphere Research Center, \\ Japan Agency for Marine-Earth Science and Technology (JAMSTEC), 2-15 Natsushima-cho, \\ Yokosuka 237-0061, Japan
}

\begin{abstract}
A novel thermophilic, sulfur-reducing chemolithoautotroph, strain $\mathrm{ABI} \mathrm{CS} 6^{\top}$, was isolated from a deep-sea hydrothermal field at the Yonaguni Knoll IV, Southern Okinawa Trough. Cells of strain $\mathrm{ABI} 70 S 6^{\top}$ were motile rods, $0.9-2.0 \mu \mathrm{m}$ in length and $0.4-0.8 \mu \mathrm{m}$ in width. Strain $\mathrm{ABI} 70 S 6^{\top}$ was an obligately anaerobic chemolithotroph, exhibiting hydrogen oxidation coupled with sulfur reduction. Growth was observed at $55-78^{\circ} \mathrm{C}$ (optimum, $70{ }^{\circ} \mathrm{C}$ ), $\mathrm{pH} 5.0-7.5$ (optimum, $\mathrm{pH} 5.5-6.0$ ) and $0.5-4.5 \% \mathrm{NaCl}$ (optimum, 3.0\% $\mathrm{NaCl}$ ). $\mathrm{H}_{2}$ and elemental sulfur were utilized as electron donor and acceptor, respectively. The major fatty acids were $\mathrm{C}_{16: 0}(40.0 \%)$ and $\mathrm{C}_{20: 1}$ (60.0\%). The $\mathrm{G}+\mathrm{C}$ content of genomic DNA was $44.2 \mathrm{~mol} \%$. The physiological attributes of strain $\mathrm{ABI} 70 \mathrm{~S}^{\top}{ }^{\top}$ are similar to those of species of genera within the family Desulfurobacteriaceae, most of which are thermophilic and chemolithoautotrophic sulfur reducers. However, 16S rRNA gene sequence similarities between the novel isolate and type strains of all species within the family Desulfurobacteriaceae were $<87 \%$, which is close to the similarities found between the novel isolate and members of the family Thermodesulfobacteriaceae $(<85 \%)$. Based on physiological and phylogenetic features of the novel isolate, it is proposed that it represents a novel species in a novel genus, Thermosulfidibacter takaii gen. nov., sp. nov., within the phylum Aquificae. The type strain of T. takaii is ABI70S6 ${ }^{\top}\left(=\mathrm{JCM} 13301^{\top}=\mathrm{DSM} 17441^{\top}\right)$.
\end{abstract}

Recent studies on microbial ecosystems in deep-sea hydrothermal environments have indicated that deeply branching, thermophilic, hydrogenotrophic and sulfidogenic bacteria in the families Desulfurobacteriaceae and Thermodesulfobacteriaceae play important roles as potential primary producers (L'Haridon et al., 2006; Nakagawa et al., 2005; Reysenbach et al., 2000a, b; Takai et al., 2004; Van Dover et al., 2001). The family Desulfurobacteriaceae, which comprises the genera Desulfurobacterium, Thermovibrio and Balnearium (L'Haridon et al., 2006; Takai et al., $2003 \mathrm{~b})$, is proposed to belong to the order Aquificales (L'Haridon et al., 2006), although the family can be differentiated physiologically and phylogenetically from the

Abbreviation: STR-ISCS, self-temperature-recording in situ colonization system.

The GenBank/EMBL/DDBJ accession number for the 16S rRNA gene sequence of $\mathrm{ABI} \mathrm{OS}^{\top}$ is $\mathrm{AB} 282756$.

Graphs showing the effects of temperature, $\mathrm{pH}$ and $\mathrm{NaCl}$ on growth of strain $\mathrm{ABI} \mathrm{OS} \mathrm{S}^{\top}$ and a phylogenetic tree of representative deeply branching members of the Bacteria including environmental phylotypes based on 16S rRNA gene sequences are available with the online version of this paper. families Aquificaceae and Hydrogenothermaceae and the possibility of establishing a new phylum for this family has been discussed (L'Haridon et al., 1998; Reysenbach, 2001). All species of the family Desulfurobacteriaceae are obligately anaerobic hydrogenotrophs that utilize elemental sulfur, sulfite and nitrate, but not oxygen or sulfate, as electron acceptors and grow optimally at relatively low temperatures $\left(<80{ }^{\circ} \mathrm{C}\right.$ ) (L'Haridon et al., 1998, 2006; L'Haridon \& Jeanthon, 2001; Reysenbach, 2001; Takai et al., 2003b) compared with members of the Aquificaceae and Hydrogenothermaceae (Eder \& Huber, 2002).

Thermodesulfobacteriaceae is the only family in the phylum Thermodesulfobacteria, which originally comprised thermophilic, strictly anaerobic and chemoheterotrophic sulfate reducers isolated from terrestrial geothermal environments (Garrity \& Holt, 2001; Hatchikian et al., 2001). On the other hand, recent isolates that have been categorized in the family Thermodesulfobacteriaceae have come from submarine and terrestrial geothermal hydrothermal systems and are hydrogenotrophic and obligate chemolithoautotrophic organisms, such as Thermodesulfobacterium hydrogeniphilum, Thermodesulfatator indicus and 
'Geothermobacterium ferrireducens' (Jeanthon et al., 2002; Kashefi et al., 2002; Moussard et al., 2004). In addition, a number of rRNA gene phylotypes detected from both terrestrial and deep-sea hydrothermal environments have been identified and these are related phylogenetically to members of the family Thermodesulfobacteriaceae (Hugenholtz et al., 1998; Nakagawa et al., 2005; Skirnisdottir et al., 2000; Van Dover et al., 2001). Thus, it seems likely that members of the family Thermodesulfobacteriaceae play important roles as primary producers in the terrestrial and deep-sea hydrothermal ecosystems in which they can be found.

Here, isolation of a novel strictly anaerobic, thermophilic chemolithoautotroph from a deep-sea hydrothermal field at the Yonaguni Knoll IV in the Southern Okinawa Trough is reported. This bacterium has a simple metabolism of hydrogen oxidation coupled with reduction of elemental sulfur, similar to that observed for members of the family Desulfurobacteriaceae. However, the newly isolated strain appears to hold a novel phylogenetic position among the deeply branching members of the class Bacteria. It is proposed that this strain represents a novel species in a novel genus, Thermosulfidibacter takaii gen. nov., sp. nov.; the type strain is $\operatorname{ABI} 06^{\mathrm{T}}\left(=\mathrm{JCM} 13301^{\mathrm{T}}=\mathrm{DSM} 17441^{\mathrm{T}}\right)$. Moreover, phylogenetic analysis and comparison of physiological properties among the novel isolate and the members of the families Desulfurobacteriaceae and Thermodesulfobacteriaceae present the possibility of novel taxonomic relationships among deeply branching members of the class Bacteria.

A self-temperature-recording in situ colonization system (STR-ISCS), described by Takai et al. (2003a), was deployed for 4 days in a hydrothermal vent site named the Abyss Vent that is present in soft sediments at the Yonaguni Knoll IV hydrothermal field in the Southern Okinawa Trough $\left(24^{\circ}\right.$ $50.769^{\prime} \mathrm{N} 122^{\circ} 42.036^{\prime}$ E) during cruise YK03-05 (July 2003) using the R/V Yokosuka and the manned submersible Shinkai 6500. The temperature of the hydrothermal fluid was $80{ }^{\circ} \mathrm{C}$. For cultivation analyses, the pumice stuffed in the recovered ISCS was stored anaerobically with MJ synthetic seawater (Sako et al., 1996) supplemented with $0.05 \%$ neutralized $\mathrm{Na}_{2} \mathrm{~S}$ in a glass bottle under $100 \% \mathrm{~N}_{2}(200 \mathrm{kPa})$ and sealed with butyl rubber stoppers. The samples were used in serial-dilution cultivation tests using various media. After culturing in MMJS medium ( $\mathrm{pH}$ 6.0), which is a modified version of MMJ medium (Takai et al., 2002) supplemented with elemental sulfur $(3 \% \mathrm{w} / \mathrm{v})$ and with a headspace gas of $80 \% \mathrm{H}_{2} / 20 \% \mathrm{CO}_{2}(200 \mathrm{kPa})$ at $70{ }^{\circ} \mathrm{C}$, the presence of short, motile rods was observed in the most diluted series $\left[<4.0 \times 10^{3}\right.$ cells (g pumice) $\left.{ }^{-1}\right]$. A pure culture of strain ABI70S6 $6^{\mathrm{T}}$ was obtained at $70{ }^{\circ} \mathrm{C}$ by using the 'serial dilution to extinction' technique (Takai et al., 2000). The purity of the isolate was tested by microscopic observation and partial sequencing of the $16 \mathrm{~S}$ rRNA gene.

Cells were observed routinely by using an Olympus BX51 microscope. Transmission electron micrographs of negatively stained and thin section cells grown in MMJS medium at $70{ }^{\circ} \mathrm{C}$ in the late-exponential phase were obtained as described by Zillig et al. (1990). The cells were straight rods, approximately $0.9-2.0 \mu \mathrm{m}$ in length and $0.4-$ $0.8 \mu \mathrm{m}$ in width (Fig. 1a, b), motile with a polar flagellum (Fig. 1a) and with both outer and inner membrane structure (Fig. 1b).

Growth of isolate was determined by direct cell counting under epifluorescence after staining with 4',6-diamidino-2phenylindole (Porter \& Feig, 1980) using an Olympus BX51 microscope. To determine the temperature, $\mathrm{pH}$ and $\mathrm{NaCl}$ concentration ranges for growth, cultures were grown in $20 \mathrm{ml}$ test tubes containing $3 \mathrm{ml}$ MMJS medium with shaking (100 r.p.m.) in a temperature-controlled drying oven. Strain ABI70S6 ${ }^{\mathrm{T}}$ grew at $55-78{ }^{\circ} \mathrm{C}$, with an optimum growth temperature of $70{ }^{\circ} \mathrm{C}$. The doubling time at the optimum temperature was $7.2 \mathrm{~h}$ and the maximum cell density observed was $2.0 \times 10^{8}$ cells ml ${ }^{-1}$. No growth was observed at 50 or $80{ }^{\circ} \mathrm{C}$. The effect of initial $\mathrm{pH}$ on growth was examined at $70{ }^{\circ} \mathrm{C}$ by using MMJS medium under a variety of $\mathrm{pH}$ conditions adjusted as described previously (Takai et al., 2005). The $\mathrm{pH}$ range for growth at $70{ }^{\circ} \mathrm{C}$ was 5.0-7.5; optimum growth was at $\mathrm{pH}$ 5.5-6.0. The range of $\mathrm{NaCl}$ concentrations in MMJS medium that supported growth at $70{ }^{\circ} \mathrm{C}$ and $\mathrm{pH} 6.0$ was $0.5-4.5 \%(\mathrm{w} / \mathrm{v}) \mathrm{NaCl}$;

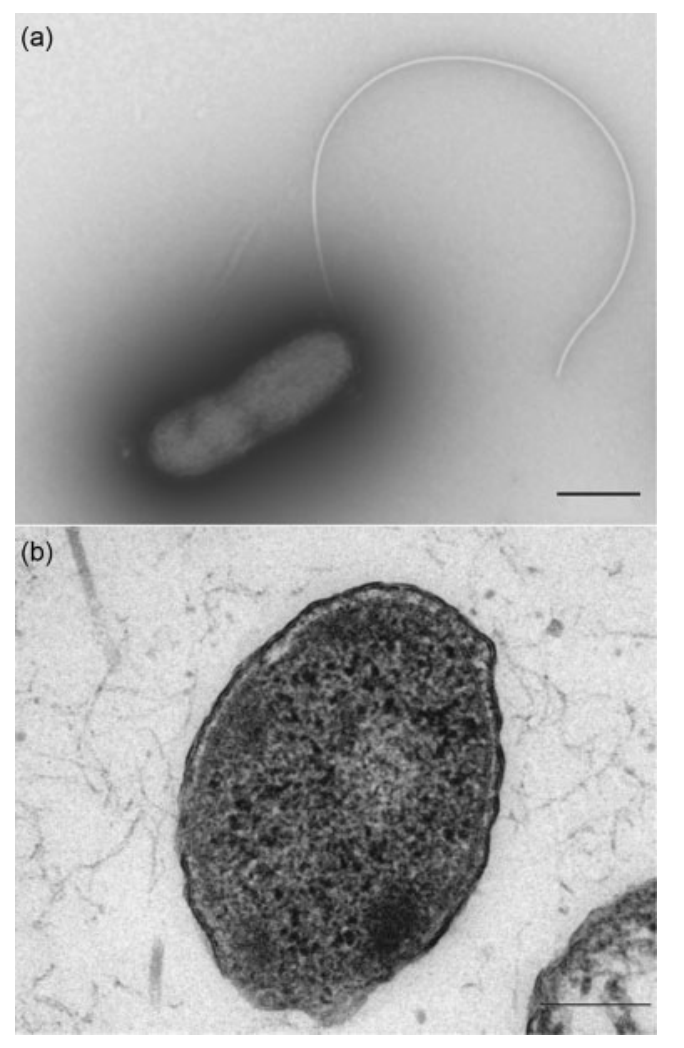

Fig. 1. Electron micrographs of a negatively stained cell (a) and a thin section (b) of strain ABI70S6 ${ }^{\top}$. Bars, $500 \mathrm{~nm}(\mathrm{a}) ; 200 \mathrm{~nm}$ (b). 
the optimum $\mathrm{NaCl}$ concentration was $3.0 \%$ (see Supplementary Fig. S1, available in IJSEM Online).

Utilization of various combinations of electron donors $\left(\mathrm{H}_{2}\right.$, elemental sulfur and thiosulfate) and acceptors (elemental sulfur, thiosulfate, sulfite, sulfate, ferrihydrite, goethite, ferric citrate, nitrate, nitrite and oxygen) were tested by using MMJ medium. The concentrations of thiosulfate, sulfite and sulfate added as sodium salts, elemental sulfur and $\mathrm{Fe}(\mathrm{III})$ were $0.1,3$ and $0.1 \%(\mathrm{w} / \mathrm{v})$, respectively. Gas mixtures of $80 \% \mathrm{H}_{2} / 20 \% \mathrm{CO}_{2}$ and $80 \%$ $\mathrm{N}_{2} / 20 \% \mathrm{CO}_{2}$ (both at $200 \mathrm{kPa}$ ) were used as the headspace gas for hydrogen and sulfur oxidation conditions, respectively. In the $\mathrm{O}_{2}$ utilization test, $\mathrm{O}_{2}(1$ and $5 \%)$ was added to the headspace gases $(200 \mathrm{kPa})$. The isolate utilized $\mathrm{H}_{2}$ as the sole energy source and elemental sulfur as the sole electron acceptor.

Nitrogen sources for growth (ammonium, nitrogen gas, nitrite and nitrate) were determined by using MMJS medium without nitrogen compounds such as $\mathrm{NH}_{4} \mathrm{Cl}$, and under $80 \% \mathrm{H}_{2} / 20 \% \mathrm{CO}_{2}(200 \mathrm{kPa})$, except when nitrogen gas was tested. $\mathrm{NH}_{4} \mathrm{Cl}, \mathrm{NaNO}_{2}$ and $\mathrm{NaNO}_{3}$ were used at $0.02 \%(\mathrm{w} / \mathrm{v})$. Nitrogen gas utilization was examined under $65 \% \mathrm{H}_{2} / 15 \% \mathrm{CO}_{2} / 20 \% \mathrm{~N}_{2}(200 \mathrm{kPa})$. Strain ABI70S6 grew with ammonium as a nitrogen source, but not with nitrogen gas, nitrate or nitrite.

Utilization of organic carbon sources was tested in the absence of $\mathrm{NaHCO}_{3}$ in MMJS medium, using $\mathrm{H}_{2}$ as the headspace gas. The following substrates were added at $0.05 \%$ (w/v): yeast extract (Difco), peptone, tryptone peptone (Difco), Casamino acids (Difco), glucose, maltose, fructose, sucrose, lactose, galactose, cellobiose, mannose, rhamnose, xylose, mannitol, glycerol, ethanol, methanol, fumarate, tartrate, acetate, formate, citrate, pyruvate, malate, propionate, succinate, mannitol, glutamate, glycine and alanine. Strain ABI70S6 ${ }^{\mathrm{T}}$ could not utilize any of the organic compounds tested in this study as a sole carbon source. The results suggest that this strain is a chemolithoautotroph.

The cellular fatty acid composition of strain $\mathrm{ABI} 70 \mathrm{~S} 6^{\mathrm{T}}$ was analysed with cells grown in MMJS medium at $70{ }^{\circ} \mathrm{C}$ and harvested at late-exponential phase using methods described previously (Takai et al., 2003b). The fatty acids detected were $\mathrm{C}_{16: 0}(40.0 \%)$ and $\mathrm{C}_{20: 0}(60.0 \%)$.

Genomic DNA was prepared as described by Lauerer et al. (1986). The G+C content was determined by direct analysis of deoxyribonucleotides by HPLC (Tamaoka \& Komagata, 1984). The G+C content of genomic DNA from strain $\mathrm{ABI} 70 \mathrm{S6}^{\mathrm{T}}$ was $44.2 \mathrm{~mol} \%$.

The 16S rRNA gene was amplified by PCR using primers Bac27F and 1492R (DeLong, 1992; Lane, 1985). The sequence of approximately $1.5 \mathrm{~kb}$ of amplified fragment was determined directly by using the deoxynucleotide chain-termination method with a DNA sequencer model 3100 (Applied Biosystems). This near-complete rRNA gene sequence (1450 bp) was analysed by using the FASTA algorithm (http://fasta.ddbj.nig.ac.jp/top-j.html). The results revealed clearly that the isolate is related only distantly to strains in known phylogenetic groups of the class Bacteria. The most closely related group was the family Desulfurobacteriaceae, and sequence similarity to rRNA genes from type strains of members of the three genera in this family (Desulfurobacterium, Balnearium and Thermovibrio) ranged from 85.0 to $86.3 \%$. The next most similar group was the family Thermodesulfobacteriaceae, which includes the genera 'Geothermobacterium', Thermodesulfobacterium and Thermodesulfatator (sequence similarities of $83.3-84.6 \%$ ).

For phylogenetic analysis, 16S rRNA gene sequences from deeply branching members of the class Bacteria and environmental phylotypes were aligned by using ARB version 20030822 (Ludwig et al., 2004) and CLUSTAL_X (Thompson et al., 1997). The environmental 16S rRNA gene phylotypes (GenBank accession numbers AB295463AB295469), except for PS-B30 and SRI-27, were retrieved from hydrothermal sediments around the Abyss Vent by PCR amplification using primers Bac27F and Bac927R (T. Nunoura and others, unpublished results). Phylogenetic topology was calculated by using unambiguously aligned nucleotide positions. Neighbour-joining analysis was performed by using CLUSTAL_X and phylogenetic topology was confirmed by maximum-likelihood and maximumparsimony analyses using PAUP version 4 (Sinauer Associates, Sunderland, MA, USA). The results of phylogenetic analyses that included strain $\mathrm{ABI} 0 \mathrm{SG}^{\mathrm{T}}$ reveal a novel phylogenetic relationship among deeply branching members of the class Bacteria. The isolate grouped phylogenetically with members of the families Desulfurobacteriaceae and Thermodesulfobacteriaceae in the cluster of the phylum Aquificae (Fig. 2). In addition, in the phylogenetic tree that includes strain $\mathrm{ABI} 0 \mathrm{S6}^{\mathrm{T}}$ and/or environmental phylotypes that were obtained from hydrothermal sediments, the family Thermodesulfobacteriaceae clustered with the Desulfurobacteriaceae and strain ABI70S6 $^{\mathrm{T}}$ within the phylum Aquificae (see Supplementary Fig. S2, available in IJSEM Online). In phylogenetic trees in previous studies, the family Desulfurobacteriaceae always appeared to be a potential sister group of the order Aquificales (L'Haridon et al., 1998, 2006; Reysenbach, 2001) and Thermodesulfobacteriaceae was the only family in the phylum Thermodesulfobacteria (Garrity \& Holt, 2001; Hatchikian et al., 2001). However, bootstrap values in previous phylogenetic topologies were always lower than those in the novel phylogenetic topology presented in this study including 16S rRNA gene sequences from novel isolates and environmental phylotypes. Therefore, we adopt the novel phylogenetic topology in this study.

Strain $\mathrm{ABI} 0 \mathrm{S6}^{\mathrm{T}}$ is similar to members of the families Desulfurobacteriaceae and Thermodesulfobacteriaceae with respect to many growth characteristics, including temperature and $\mathrm{pH}$ ranges for growth, morphology and obligately anaerobic hydrogenotrophy (Table 1). 


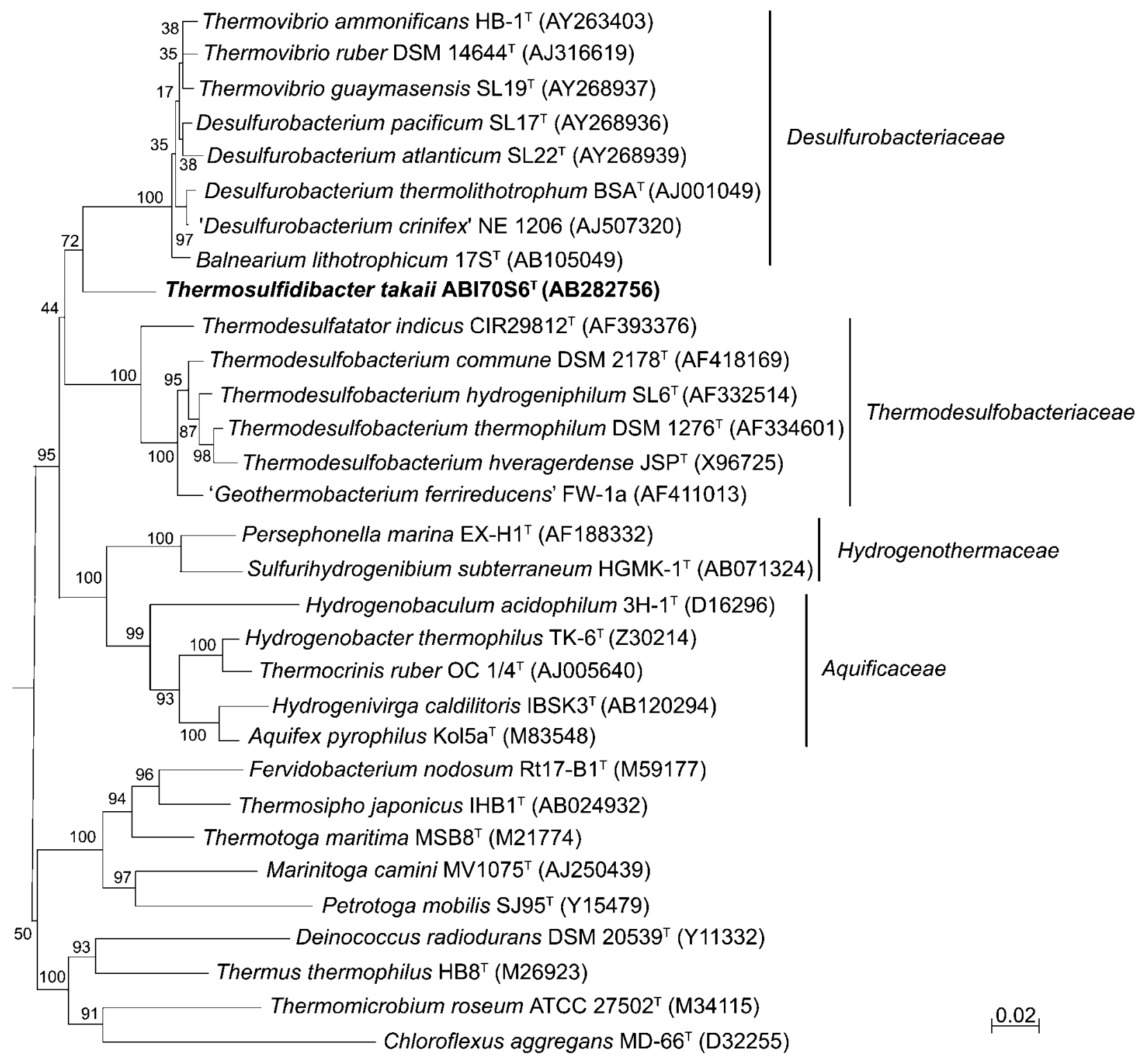

Fig. 2. Phylogenetic tree of representative deeply branching members of the class Bacteria based on 16S rRNA gene sequences. The tree was constructed by the neighbour-joining method, using 1038 sequence positions for each organism. Numbers at nodes indicate bootstrap values from 100 trials. GenBank/EMBL/DDBJ accession numbers are given in parentheses. Thermococcus celer (M21529), Methanocaldococcus jannaschii (M59126), Desulfurococcus mobilis (X06188) and Pyrobaculum oguniense (AB029339) were used as the outgroup. Bar, two substitutions per 100 nt.

Regarding utilization of electron acceptors, the isolate is able to use only elemental sulfur. This is similar to the electron acceptor-utilization profiles of members of the family Desulfurobacteriaceae, most of which use elemental sulfur as their primary electron acceptor, but differs from members of the family Thermodesulfobacteriaceae, which use sulfate or $\mathrm{Fe}(\mathrm{III})$ as the primary electron acceptor (Table 1). However, 16S rRNA gene sequence similarity between strain $\mathrm{ABI} 70 \mathrm{~S} 6^{\mathrm{T}}$ and any previously described species in the family Desulfurobacteriaceae is $<87 \%$, which is lower than the index value of the genus level of differentiation (Gillis et al., 2001). Therefore, strain $\mathrm{ABI70S6}^{\mathrm{T}}$ represents a novel species in a novel genus, for which the name Thermosulfidibacter takaii gen. nov., sp. nov. is proposed; the type strain is $\mathrm{ABI}^{\mathrm{B}} 0 \mathrm{S6}^{\mathrm{T}}$ (=JCM $\left.13301^{\mathrm{T}}=\mathrm{DSM} 17441^{\mathrm{T}}\right)$. This species is physiologically and morphologically similar to members of the family Desulfurobacteriaceae, as described above, and formed a sister cluster in the phylogenetic tree (Fig. 2). However, phylogenetic distances between Thermosulfidibacter takaii and members of the families Desulfurobacteriaceae and Thermodesulfobacteriaceae are nearly equivalent, the 
Table 1. Characteristics of Thermosulfidibacter takaii and members of the families Desulfurobacteriaceae and Thermodesulfobacteriaceae

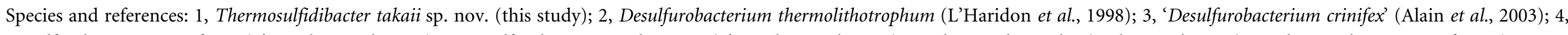

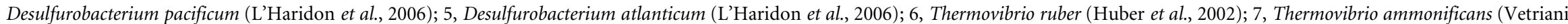

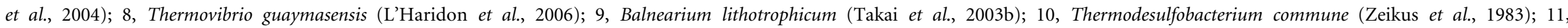

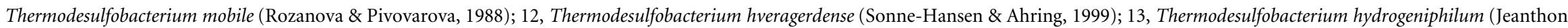

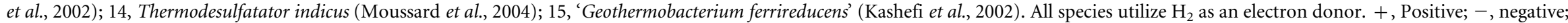
ND, not determined; ${ }^{\text {HPLC }}$, determined by HPLC method; ${ }^{\mathrm{TM}}$, determined by $T_{\mathrm{m}}$ method.

\begin{tabular}{|c|c|c|c|c|c|c|c|c|c|c|c|c|c|c|c|}
\hline Character & 1 & 2 & 3 & 4 & 5 & 6 & 7 & 8 & 9 & 10 & 11 & 12 & 13 & 14 & 15 \\
\hline $\begin{array}{l}\text { DNA G }+C \text { content } \\
(\mathrm{mol} \%)\end{array}$ & $44.2^{\mathrm{HPLC}}$ & $35^{\mathrm{TM}}$ & $37^{\mathrm{HPLC}}$ & $42^{\mathrm{HPLC}}$ & $41^{\text {HPLC }}$ & $45^{\mathrm{TM}}$ & $54.6^{\mathrm{HPLC}}$ & $46^{\mathrm{HPLC}}$ & $34.6^{\mathrm{HPLC}}$ & $34.4^{\mathrm{TM}}$ & $38^{\mathrm{TM}}$ & $40^{\mathrm{HPLC}}$ & $28^{\mathrm{TM}}$ & $46^{\mathrm{HPLC}}$ & ND \\
\hline $\begin{array}{l}\text { Temperature range } \\
\left({ }^{\circ} \mathrm{C}\right)\end{array}$ & $55-78$ & $40-75$ & $50-70$ & $55-85$ & $50-80$ & $50-80$ & $60-80$ & $50-88$ & $45-80$ & $45-82$ & $45-85$ & $55-74$ & $50-80$ & $55-80$ & $65-100$ \\
\hline $\begin{array}{l}\text { Optimal temperature } \\
\left({ }^{\circ} \mathrm{C}\right)\end{array}$ & 70 & 70 & $60-65$ & 75 & $70-75$ & 75 & 75 & $75-80$ & $70-75$ & 70 & 65 & $70-74$ & 75 & 70 & 85-90 \\
\hline $\mathrm{NaCl}$ range $(\%)$ & $0.5-4.5$ & $1.5-7.0^{\star}$ & $2.0-4.0^{\star}$ & $1.5-5.0$ & $1.5-5.0$ & $2.0-4.7$ & $0.5-4.5$ & $1.5-5.0$ & $0.8-5.6$ & $<2.0$ & $<2.0$ & ND & $0.5-5.5$ & $1.0-3.5$ & $0.0-0.75$ \\
\hline Optimal $\mathrm{NaCl}(\%)$ & 3 & $3.5^{\star}$ & 3 & 3 & 3 & 3 & 2 & 3 & 3.2 & 0 & $0.05-1.0$ & ND & 3 & 2.5 & $0.0-0.05$ \\
\hline $\mathrm{pH}$ range & $5.0-7.5$ & $4.4-8.0$ & $5.0-7.5$ & $5.5-7.5$ & $5.5-7.0$ & $5.0-6.5$ & $5.0-7.0$ & $5.5-7.5$ & $5.0-7.0$ & $6.0-8.0$ & $\mathrm{ND}$ & ND & $6.3-6.8$ & $6.0-6.7$ & ND \\
\hline Optimal pH & $5.5-6.0$ & $6.0-6.5$ & $6.0-6.5$ & $6.0-6.2$ & $5.8-6.0$ & 6.0 & 5.5 & $6.0-6.2$ & 5.4 & 7.0 & $\mathrm{ND}$ & $\mathrm{ND}$ & 6.5 & 6.25 & $6.8-7.0$ \\
\hline \multicolumn{16}{|l|}{ Electron donors: } \\
\hline Pyruvate & - & - & - & - & - & - & - & - & - & + & + & + & - & - & - \\
\hline Lactate & - & - & - & - & - & - & - & - & - & + & + & + & - & - & - \\
\hline Fermentation & - & - & - & - & - & - & - & - & - & + & + & + & - & - & - \\
\hline \multicolumn{16}{|l|}{ Electron acceptors: } \\
\hline Polysulfide & $\mathrm{ND}$ & + & - & $\mathrm{ND}$ & ND & ND & $\mathrm{ND}$ & $\mathrm{ND}$ & $\mathrm{ND}$ & ND & $\mathrm{ND}$ & ND & ND & ND & - \\
\hline Sulfur & + & + & + & + & - & + & + & + & + & $\mathrm{ND}$ & $\mathrm{ND}$ & - & - & - & - \\
\hline Thiosulfate & - & + & - & + & + & - & - & - & - & + & + & + & - & - & - \\
\hline Sulfite & - & + & - & - & - & - & - & - & - & - & + & + & - & - & - \\
\hline Sulfate & - & - & - & - & - & - & - & - & - & + & + & + & + & + & - \\
\hline Nitrate & - & - & + & + & - & + & + & + & - & - & $\mathrm{ND}$ & - & - & - & - \\
\hline $\mathrm{Fe}(\mathrm{III})$ & - & ND & - & ND & $\mathrm{ND}$ & $\mathrm{ND}$ & $\mathrm{ND}$ & $\mathrm{ND}$ & - & $\mathrm{ND}$ & $\mathrm{ND}$ & $\mathrm{ND}$ & ND & ND & + \\
\hline \multicolumn{16}{|l|}{ Nitrogen sources: } \\
\hline Ammonium & + & - & ND & - & - & ND & ND & - & + & ND & ND & ND & ND & + & ND \\
\hline Nitrate & - & + & ND & + & + & + & ND & + & - & ND & ND & ND & ND & - & ND \\
\hline \multirow[t]{2}{*}{ Cell size $(\mu \mathrm{m})$} & $0.4-0.8$ & $0.4-0.5$ & $0.4-0.7$ & $0.4-0.5$ & $0.4-0.5$ & $0.5-0.8$ & $0.6 \times 1.0$ & $1.0-2.0$ & $0.7-0.9$ & $0.3 \times 0.9$ & $0.6 \times 2.0$ & $0.5 \times 2.8$ & $0.4-0.5$ & $0.4-0.5$ & 0.5 \\
\hline & $\times 0.9-2.0$ & $\times 1.0-2.0$ & $\times 0.9-3.5$ & $\times 1.0-2.0$ & $\times 2.5-3.5$ & $\times 1.5-3.0$ & & $\times 1.0-2.0$ & $\times 2.5-3.5$ & & & & $\times 0.5-0.8$ & $\times 0.8-1.0$ & $\begin{array}{c}\times 1.0- \\
1.2\end{array}$ \\
\hline
\end{tabular}

${ }^{*}$ Sea salts concentration. 
topology between Thermosulfidibacter takaii and the families Desulfurobacteriaceae and Thermodesulfobacteriaceae is not stable (Fig. 2; Supplementary Fig. S2, available in IJSEM Online), and the phylogenetic tree including environmental phylotypes presents a novel cluster comprising strain $\mathrm{ABI} \mathrm{SS}^{\mathrm{T}}$ and environmental phylotypes (Supplementary Fig. S2). Accordingly, the genus Thermosulfidibacter does not seem to belong to either of the families Desulfurobacteriaceae or Thermodesulfobacteriaceae, but probably represents a novel family; the genus Thermosulfidibacter and the families Desulfurobacteriaceae and Thermodesulfobacteriaceae have the potential of forming a novel order in the phylum Aquificae.

\section{Description of Thermosulfidibacter gen. nov.}

Thermosulfidibacter (Ther.mo.sul.fi.di.bac'ter. Gr. fem. n. therme heat; N.L. n. sulfidum sulfide; L. masc. n. bacter a rod; N.L. masc. n. Thermosulfidibacter a thermophilic, sulfide-producing, rod-shaped bacterium).

Gram-negative rods. Spores are not formed. Anaerobic, thermophilic and neutrophilic. Strictly chemolithoautotrophic. The type species is Thermosulfidibacter takaii.

\section{Description of Thermosulfidibacter takaii sp. nov.}

Thermosulfidibacter takaii (ta.kai'i. N.L. gen. n. takaii of Takai, named after Dr Ken Takai, a microbiologist who has devoted himself to the study of terrestrial and deep-sea hydrothermal microbial ecosystems and chemolithoautotrophs present in those environments).

Motile rods, $0.9-2.0 \times 0.4-0.8 \mu \mathrm{m}$, with a polar flagellum. Strictly anaerobic. Growth occurs at $55-78{ }^{\circ} \mathrm{C}$ (optimum, $70{ }^{\circ} \mathrm{C}$ ), $\mathrm{pH}$ 5.0-7.5 (optimum, $\mathrm{pH} 5.5-6.0$ ) and $0.5-4.5 \%$ $\mathrm{NaCl}$ (optimum, $3.0 \% \mathrm{NaCl}$ ). $\mathrm{H}_{2}$ and elemental sulfur are utilized as electron donor and acceptor, respectively, and hydrogen sulfide is produced. Major fatty acids are $\mathrm{C}_{16: 0}$ $(40.0 \%)$ and $\mathrm{C}_{20: 1}(60.0 \%)$. Ammonium is required as a nitrogen source.

The type strain is $\mathrm{ABI} 06^{\mathrm{T}} \quad\left(=\mathrm{JCM} \quad 13301^{\mathrm{T}}=\mathrm{DSM}\right.$ $\left.17441^{\mathrm{T}}\right)$, isolated from an STR-ISCS deployed in a hydrothermal vent site at the Yonaguni Knoll IV field, Southern Okinawa Trough. The DNA G $+\mathrm{C}$ content of the type strain is $44.2 \mathrm{~mol} \%$.

\section{Acknowledgements}

We would like to thank Dr Katsuyuki Uematsu for assistance with electron micrographs. We also appreciate the R/V Yokosuka and Shinkai 6500 operation team for their assistance in collecting samples.

\section{References}

Alain, K., Rolland, S., Crassous, P., Lesongeur, F., Zbinden, M., Le Gall, C., Godfroy, A., Page, A., Juniper, S. K. \& other authors (2003). Desulfurobacterium crinifex sp. nov., a novel thermophilic, pinkishstreamer forming, chemolithoautotrophic bacterium isolated from a
Juan de Fuca Ridge hydrothermal vent and amendment of the genus Desulfurobacterium. Extremophiles 7, 361-370.

DeLong, E. F. (1992). Archaea in coastal marine environments. Proc Natl Acad Sci U S A 89, 5685-5689.

Eder, W. \& Huber, R. (2002). New isolates and physiological properties of the Aquificales and description of Thermocrinis albus sp. nov. Extremophiles 6, 309-318.

Garrity, G. M. \& Holt, J. G. (2001). Phylum BIII. Thermodesulfobacteria phy. nov. In Bergey's Manual of Systematic Bacteriology, 2nd edn, vol. 1, pp. 389-393. Edited by D. R. Boone, R. W. Castenholz \& G. M. Garrity. New York: Springer.

Gillis, M., Vandamme, P., De Vos, P., Swings, J. \& Kersters, K. (2001). Polyphasic taxonomy. In Bergey's Manual of Systematic Bacteriology, 2nd edn, vol. 1, pp. 43-48. Edited by D. R. Boone, R. W. Castenholz \& G. M. Garrity. New York: Springer.

Hatchikian, E. C., Ollivier, B. \& Garcia, J.-J. (2001). Family I. Thermodesulfobacteriaceae fam. nov. In Bergey's Manual of Systematic Bacteriology, 2nd edn, vol. 1, p. 390. Edited by D. R. Boone, R. W. Castenholz \& G. M. Garrity. New York: Springer.

Huber, H., Diller, S., Horn, C. \& Rachel, R. (2002). Thermovibrio ruber gen. nov., sp. nov., an extremely thermophilic, chemolithoautotrophic, nitrate-reducing bacterium that forms a deep branch within the phylum Aquificae. Int J Syst Evol Microbiol 52, 1859-1865.

Hugenholtz, P., Pitulle, C., Herschberger, K. L. \& Pace, N. R. (1998). Novel division level bacterial diversity in a Yellowstone hot spring. J Bacteriol 180, 366-376.

Jeanthon, C., L'Haridon, S., Cueff, V., Banta, A., Reysenbach, A. L. \& Prieur, D. (2002). Thermodesulfobacterium hydrogeniphilum sp. nov., a thermophilic, chemolithoautotrophic, sulfate-reducing bacterium isolated from a deep-sea hydrothermal vent at Guaymas Basin, and emendation of the genus Thermodesulfobacterium. Int J Syst Evol Microbiol 52, 765-772.

Kashefi, K., Holmes, D. E., Reysenbach, A. L. \& Lovley, D. R. (2002). Use of $\mathrm{Fe}(\mathrm{III})$ as an electron acceptor to recover previously uncultured hyperthermophiles: isolation and characterization of Geothermobacterium ferrireducens gen. nov., sp. nov. Appl Environ Microbiol 68, 1735-1742.

L'Haridon, S. \& Jeanthon, C. (2001). Genus incertae sedis I. Desulfurobacterium. In Bergey's Manual of Systematic Bacteriology, 2nd edn, vol. 1, pp. 366-367. Edited by D. R. Boone, R. W. Castenholz \& G. M. Garrity. New York: Springer.

L'Haridon, S., Cilia, V., Messner, P., Raguenes, G., Gambacorta, A., Sleytr, U. B., Prieur, D. \& Jeanthon, C. (1998). Desulfurobacterium thermolithotrophum gen. nov., sp. nov., a novel autotrophic, sulphurreducing bacterium isolated from a deep-sea hydrothermal vent. Int $J$ Syst Bacteriol 48, 701-711.

L'Haridon, S., Reysenbach, A.-L., Tindall, B. J., Schönheit, P., Banta, A., Johnsen, U., Schumann, P., Gambacorta, A., Stackebrandt, E. \& Jeanthon, C. (2006). Desulfurobacterium atlanticum sp. nov., Desulfurobacterium pacificum sp. nov. and Thermovibrio guaymasensis sp. nov., three thermophilic members of the Desulfurobacteriaceae fam. nov., a deep branching lineage within Bacteria. Int J Syst Evol Microbiol 56, 2843-2852.

Lane, D. J. (1985). 16S/23S rRNA sequencing. In Nucleic Acid Techniques in Bacterial Systematics, pp. 115-175. Edited by E. Stackebrandt \& M. Goodfellow. Chichester: Wiley.

Lauerer, G., Kristjansson, J. K., Langworthy, T. A., König, H. \& Stetter, K. O. (1986). Methanothermus sociabilis sp. nov., a second species within the Methanothermaceae growing at $97{ }^{\circ} \mathrm{C}$. Syst Appl Microbiol 8, 100-105.

Ludwig, W., Strunk, O., Westram, R., Richter, L., Meier, H., Yadhukumar, Buchner, A., Lai, T., Steppi, S. \& other authors 
(2004). ARB: a software environment for sequence data. Nucleic Acids Res 32, 1363-1371.

Moussard, H., L'Haridon, S., Tindall, B. J., Banta, A., Schumann, P., Stackebrandt, E., Reysenbach, A. L. \& Jeanthon, C. (2004). Thermodesulfatator indicus gen. nov., sp. nov., a novel thermophilic chemolithoautotrophic sulfate-reducing bacterium isolated from the Central Indian Ridge. Int J Syst Evol Microbiol 54, 227-233.

Nakagawa, S., Takai, K., Inagaki, F., Chiba, H., Ishibashi, J., Kataoka, S., Hirayama, H., Nunoura, T., Horikoshi, K. \& Sako, Y. (2005). Variability in microbial community and venting chemistry in a sediment-hosted backarc hydrothermal system: impacts of subseafloor phase-separation. FEMS Microbiol Ecol 54, 141-155.

Porter, K. G. \& Feig, Y. S. (1980). The use of DAPI for identifying and counting aquatic microflora. Limnol Oceanogr 25, 943-948.

Reysenbach, A.-L. (2001). Phylum BI. Aquificae phy. nov. In Bergey's Manual of Systematic Bacteriology, 2nd edn, vol. 1, pp. 359-367. Edited by D. R. Boone, R. W. Castenholz \& G. M. Garrity. New York: Springer.

Reysenbach, A.-L., Banta, A. B., Boone, D. R., Cary, S. C. \& Luther, G. W. (2000a). Microbial essentials at hydrothermal vents. Nature 404, 835.

Reysenbach, A.-L., Longnecker, K. \& Kirshtein, J. (2000b). Novel bacterial and archaeal lineages from an in situ growth chamber deployed at a Mid-Atlantic Ridge hydrothermal vent. Appl Environ Microbiol 66, 3798-3806.

Rozanova, E. P. \& Pivovarova, T. A. (1988). Reclassification of Desulfovibrio thermophilus (Rozanova \& Khudyakova, 1974). Mikrobiologiya 57, 102-106 (in Russian).

Sako, Y., Takai, K., Ishida, Y., Uchida, A. \& Katayama, Y. (1996). Rhodothermus obamensis sp. nov., a modern lineage of extremely thermophilic marine bacteria. Int J Syst Bacteriol 46, 1099-1104.

Skirnisdottir, S., Hreggvidsson, G. O., Hjörleifsdottir, S., Marteinsson, V. T., Petursdottir, S. K., Holst, O. \& Kristjansson, J. K. (2000). Influence of sulfide and temperature on species composition and community structure of hot spring microbial mats. Appl Environ Microbiol 66, 2835-2841.

Sonne-Hansen, J. \& Ahring, B. K. (1999). Thermodesulfobacterium hveragerdense sp. nov., and Thermodesulfovibrio islandicus sp. nov., two thermophilic sulfate reducing bacteria isolated from a Icelandic hot spring. Syst Appl Microbiol 22, 559-564.

Takai, K., Sugai, A., Itoh, T. \& Horikoshi, K. (2000). Palaeococcus ferrophilus gen. nov., sp. nov., a barophilic, hyperthermophilic archaeon from a deep-sea hydrothermal vent chimney. Int J Syst Evol Microbiol 50, 489-500.

Takai, K., Inoue, A. \& Horikoshi, K. (2002). Methanothermococcus okinawensis sp. nov., a thermophilic, methane-producing archaeon isolated from a Western Pacific deep-sea hydrothermal vent system. Int J Syst Evol Microbiol 52, 1089-1095.

Takai, K., Inagaki, F., Nakagawa, S., Hirayama, H., Nunoura, T., Sako, Y., Nealson, K. H. \& Horikoshi, K. (2003a). Isolation and phylogenetic diversity of members of previously uncultivated epsilonProteobacteria in deep-sea hydrothermal fields. FEMS Microbiol Lett 218, 167-174.

Takai, K., Nakagawa, S., Sako, Y. \& Horikoshi, K. (2003b). Balnearium lithotrophicum gen. nov., sp. nov., a novel thermophilic, strictly anaerobic, hydrogen-oxidizing chemolithoautotroph isolated from a black smoker chimney in the Suiyo Seamount hydrothermal system. Int J Syst Evol Microbiol 53, 1947-1954.

Takai, K., Gamo, T., Tsunogai, U., Nakayama, N., Hirayama, H., Nealson, K. H. \& Horikoshi, K. (2004). Geochemical and microbiological evidence for a hydrogen-based, hyperthermophilic subsurface lithoautotrophic microbial ecosystem (HyperSLiME) beneath an active deep-sea hydrothermal field. Extremophiles 8, 269-282.

Takai, K., Hirayama, H., Nakagawa, T., Suzuki, Y., Nealson, K. H. \& Horikoshi, K. (2005). Lebetimonas acidiphila gen. nov., sp. nov., a novel thermophilic, acidophilic, hydrogen-oxidizing chemolithoautotroph within the 'Epsilonproteobacteria', isolated from a deep-sea hydrothermal fumarole in the Mariana Arc. Int J Syst Evol Microbiol 55, 183-189.

Tamaoka, J. \& Komagata, K. (1984). Determination of DNA base composition by reversed-phase high-performance liquid chromatography. FEMS Microbiol Lett 25, 125-128.

Thompson, J. D., Gibson, T. J., Plewniak, F., Jeanmougin, F. \& Higgins, D. G. (1997). The CLUSTAL_X windows interface: flexible strategies for multiple sequence alignment aided by quality analysis tools. Nucleic Acids Res 25, 4876-4882.

Van Dover, C. L., Humphris, S. E., Fornari, D., Cavanaugh, C. M., Collier, R., Goffredi, S. K., Hashimoto, J., Lilley, M. D., Reysenbach, A. L. \& other authors (2001). Biogeography and ecological setting of Indian Ocean hydrothermal vents. Science 294, 818-823.

Vetriani, C., Speck, M. D., Ellor, S. V., Lutz, R. A. \& Starovoytov, V. (2004). Thermovibrio ammonificans sp. nov., a thermophilic, chemolithotrophic, nitrate-ammonifying bacterium from deep-sea hydrothermal vents. Int J Syst Evol Microbiol 54, 175-181.

Zeikus, J. G., Dawson, M. A., Thompson, T. E., Ingvorsen, K. \& Hatchikian, E. C. (1983). Microbial ecology of volcanic sulphidogenesis: isolation and characterization of Thermodesulfobacterium commune gen. nov. and sp. nov. J Gen Microbiol 129, 1159-1169.

Zillig, W., Holz, I., Janekovic, D., Klenk, H. P., Imsel, E., Trent, J., Wunderl, S., Forjaz, V. H., Coutinho, R. \& Ferreira, T. (1990). Hyperthermus butylicus, a hyperthermophilic sulfur-reducing archaebacterium that ferments peptides. J Bacteriol 172, 3959-3965. 